\title{
Fight Terrorism with Philosophical Reason
}

\author{
$1^{\text {st }}$ Agus Satmoko Adi \\ Pancasila \& Civic Education \\ Department, Facult of Social Sciences \\ and Law \\ Universitas Negeri Surabaya \\ Surabaya, Indonesia \\ agussatmoko@unesa.ac.id
}

\author{
$2^{\text {nd }}$ Warsono \\ Pancasila \& Civic Education \\ Department, Facult of Social Sciences \\ and Law \\ Universitas Negeri Surabaya \\ Surabaya, Indonesia \\ warsono@unesa.ac.id
}

\author{
$3^{\text {rd }}$ Abdul Latif \\ Pancasila \& Civic Education \\ Department, Faculty of Social Sciences \\ Universitas Negeri Makassar \\ Makassar Indonesia
}

\begin{abstract}
The phenomenon of terrorism is discussed and has always been a hot issue since the events of September 11 in WTC, Bali I and II bombings, JW Marriot haotel and Ritz Carlton and the latest suicide bombings in 3 churches in Surabaya conducted by a family. Terrorism as an act of violence for the purposes of coercion of wills, coercion, and publication that takes the victims of innocent civilian shows a very close relationship with politics. Thinking philosophically, seeking principles, pursuing the truth, and seeking clarity are unlikely to work well without rational thought. Thinking rationally means thinking logically, systematically, and critically. Logical thinking is not merely achieving notions acceptable to common sense, but also in order to be able to draw conclusions and take the correct and correct decisions of the premises used. Meanwhile, terrorism and radicalism uses ideological and religious means to define the situation, legitimize actions and persuade supporters. Ideological and religious means are called framing. Framing is an effort to make the framework think and reiterate the political and economic interests behind a radical movement.
\end{abstract}

\section{Keywords-Terrorism, philosophical reason}

\section{INTRODUCTION}

Terrorism is defined as the use of terror as a symbolic act designed to influence political policies and behaviors through extreme ways, especially using violence and threats of violence. In terrorism, the use of violent ways and causing terror are seen as a legitimate way to achieve objectives. Acts of terrorism have of three elements namely: firsts, Acts or threats of violence. Second, emotional reactions is to be extremed the fear from the victims or potential victims. Three, Social impacts following the violence or threats of violence as an aftermath.[1]

The phenomenon of terrorism is discussed and has always been a hot issue since the events of September 11 in WTC, Bali I and II bombings, JW Marriot haotel and Ritz Carlton and the latest suicide bombings in 3 churches in Surabaya conducted by a family. Of course, this series of bombing tragedies is a major blow to the Indonesian nation. Terror and suffering are images that may never be completely avoided. Efforts to describe the suffering born of terror and conflict will never be enough to adequately describe what really happened.

Terrorism as an act of violence for the purposes of coercion of wills, coercion, and publication that takes the victims of innocent civilians shows a very close relationship with politics. Acts of terror and violence are often perpetrated by groups who feel politically disadvantaged. It has been widely demonstrated that politics and terrorism are related to each other. If the flow of political communications is clogged, in the sense that the mass media and the people's representatives system are ineffective and unable to fulfill the people's aspirations, then terrorism arises. Terrorism is the same as war that is diplomacy through other means. Terrorism comes from a sense of political discontent and frustration.[2]

Scientific critique and academic autonomy are compromised if a social phenomenon, as destructive in its effects as terrorism, is under the pressure of nonscientificinterestsnotobservedinthecontextofsimilarphenome nathathave as destructive effects as terrorism but are called other names or are not treated as equally destructive. These phenomena result from the social relations founded upon the root difference in power distribution, whereby one social actor (an individual or a group) seizes the status of the "stronger" one based on the greater amount of initial or subsequently gained power and thus succeeds in imposing his or her will to the "weaker" one against his or her consent (Weber, 1999), and acquires consequently from that kind of relationship a relatively permanent gain or realizes an intended interest. The relationship between the rich and the poor is developed out of or parallel to this relationship between the stronger and the weaker, whereby greater power and wealth are accumulated on the same side.[3]

Terrorism is often rooted in religious views. For a fuller explanation of this, Kimbal not only explains situations where religion is integrated with violence, but also explains the principle of religious diversity (pluralist view) as a multicultural and interfaith relationship. According to Kimbal, every religion does have its own way of salvation so that a truth claim that makes religion "potentially" bear violence must be rejected.[4]

As with today's terrorism is often identified with Islam. Although this view is seen as oversimplification.Because Islam is essentially not enjoining its people to commit acts of violence or terrorism. This is only the result of a narrow interpretation of a group of people who profess Islam. They claim that their actions derive authentic legitimacy from the teachings of Islam. Religious views like this actually occur also in various religions. In every religion there is always a puritanical, fundamentalist and extremist group. 
This claim is usually followed by the efforts of clerics to distinguish between true and authentic religions which are seen as simply calling for peace with a false and inauthentic religion that is considered more fundamentalist and extremist militant. This view denounces political leaders who carry religion for their own political and economic interests. Religion thus must be sterilized from the tragic consequences arising from the rotten intentions of the political leader.

Terrorism reflects action with the argument of necessity. The argument of necessity is not an ethical argument. Ethics is the result of choice. Must be ignored choices. The idea that leads to the choice of violence is plausible, but not a moral one. Terrorism is a form of nihilism because of three distinctive features, namely the death of freedom, the dominance of violence and the enslavement of thought.Subterranean turmoil that now affects social, state and intellectual life in all countries will sooner or later give unexpected results. The collapse of moral authority in the previous period meant that layers of youth especially in various parts of the world had now fallen into the influence of things such as religious fundamentalism and terrorism. But when they begin to understand the limits of these false ideas, they will move beyond them and look for alternatives that are considered more satisfying. We are indeed experiencing a culture of silting everywhere, including religion.

The philosophical solutions of theological violence, especially those involving stimuli from outside of the human self, are useful in the context of creating a strategy to challenge and overcome all forms of injustice, poverty, ignorance and so forth, in a structural environment of a society, both in a local, domestic context (national) and global (international).

The country and its bureaucratic instruments, and international political organizations, are obliged to create a balance of life among their citizens and minimize the potential for injustice, alleviate poverty and ignorance, and solve other societal problems. With the intervention of the state and international political organization, solving the problem of theological violence is expected to touch the roots of the problem. This simulative effort must also be accompanied by the willingness of religious circles to invite religious people to non-violence militancy

\section{RESEARCH METHODS}

The approach used in this study is a qualitative approach that is a research approach without using statistics but with the descriptive exposure is trying to describe a symptom or event, the current incident, where the researcher tried to photograph a peritiwa and events that became the focus of attention to later described as is. This study uses case study design to look at the social phenomena that occur, the background, and the effects of the event. Then the researchers provide philosophical solutions to overcome theological and terrorism violence.

\section{RESULT AND DISCUSSION}

Philosophizing means to think radically. Philosophers are radical thinkers. And because of radical thinking he never fixated on only one particular phenomenon. He will not stop at one particular answer. By radical thinking, philosophy seeks to find answers to the root of the problem. Philosophy seeks to find out the true nature of everything.

Thinking radically does not mean to change, discard, or overturn everything, but in the sense of trying to think deeply, to find the root of the problem in question. Radical thinking seeks to clarify reality, through the discovery and understanding of the roots of reality itself. Philosophy not only refers to a particular part of reality, but seeks to seek the whole. In view of the whole of reality, philosophy always seeks to find the most essential principle of the whole reality. Finding the principle means trying to find something that is the essence of reality. By discovering the essence of a reality, that reality can be known with certainty and become clear. Finding principles is one of the basic properties of philosophy.

The philosopher is essentially a hunter of truth. The truth he pursues is the ultimate truth about all reality and everything that can be questioned. So it can be said that philosophizing means hunting the truth about everything. What the name of truth itself must be accountable for. That is, the truth must always be open to question again and tested in order to gain a more certain truth. Therefore it can be said that truth in the sense of philosophy is never absolute and final, but always moving from one truth to a new, more certain truth.

Thinking radically, seeking principles, pursuing the truth, and seeking clarity are unlikely to work well without rational thought. Thinking rationally means thinking logically, systematically, and critically. Logical thinking is not merely achieving notions acceptable to common sense, but also in order to be able to draw conclusions and take the correct and correct decisions of the premises used

Logical thinking also requires systematic thinking. Systematic thinking is a series of thoughts that are related to each other or logically related. Without accompanied by logical-systematic and coherent thinking, it is impossible to achieve truth that can be accounted for. Critical thinking means keeping the will to constantly evaluate arguments that claim to be true. A person who is critical thinking will not easily believe in a truth without actually testing the validity of the truth.

Terrorism is the premeditated use or threat to use violence by individuals or subnational groups to obtain a political or social objective through the intimidation of a large audience beyond that of the immediate victims. The key ingredients in this definition concern the politicalor social objective, the non-state perpetrator, and the need for a large audience. Violence for non-political goals -e.g. a kidnapping for ransom, not intended to promote a political agenda - is a crime, but is not terrorism. If the perpetrator is a state, then state terrorism results. Although state terrorism is an important concern, it is not the terrorism that is addressed in the special issue.

Finally, terrorists want a large audience to feel at risk so that public pressures are applied to officeholders or rulers to 
concede terrorists' demands for change. To create this general atmosphere of fear, terrorists engage in various types of operations - kidnappings, bombings, assassinations, hijackings, and armed attacks - in a seemingly random fashion so that everyone feels in jeopardy. But in fact, these attacks are not random; instead, terrorists trade off risk and return when choosing their tar- gets. Soft, high-valued targets are particularly attractive. Terrorism is a tactic of the weak to deploy against the strong. With a carefully planned and executed campaign, small groups of extremists may effectively use violence to gain a presence. Even though governments seldom cave in to terrorist demands, 1 these campaigns can still have many deleterious effects - e.g. a general sense of fear or restrictions on civil liberties - on targeted societies. Governments may have to spend heavily on counter-terrorism measures that raise taxes and divert public moneys from more productive activities. [5]

Terrorism and radicalism uses ideological and religious means to define the situation, legitimize actions and persuade supporters. Ideological and religious means are called framing. Framing is an effort to make the framework think and reiterate the political and economic interests behind a radical movement. In religious communities, framing which is very effective is certainly religious framing. It is through this religious framing that contemporary situations, for example, are defined as jahiliyah or taghut. By framing religion, actions to fight jahiliyah and toghut are called amarma'rufnahimunkar and jihad. While the deaths of the struggle against ignorance and taghut it is called as dead in the way of Allah Shaheed. Another framing function of religion is to persuade others to support radical acts such as terrorism. This is where people who do not support are defined as infidels and enemies while those who welcome persuasion are called ikhwan and akhawat.

The problem is where is the reason for the violence that is the basis of radicalism? In simple terms, epistemological violence is built on basic assumptions about reality, basic assumptions about religion and how religions deal with that reality. The perpetrators and supporters of radicalism are the most active and productive groups introducing narratives, especially religious narratives. It is so active and productive that there is little activity in the personal, communal and structural spaces that are not defined by religious language frames. They believe that their religion is perfect (kamil) and comprehensive (syamil).

The religious narratives that are always heralded by radicals are past textual narratives that are understood regardless of the dimensions of space and time. In the view of radicals, religious texts are not related to space (locus) and time (tempus).The sacred texts are a set of teaching systems that overcome the social history of human life. Because of its character over time and space the religious text is fixed, both from the word and the content of its meaning. Therefore, the reality and development of human life must be completely subject to the text.

As a consequence of this kind of reasoning, radical groups view life as a lifelong jihad to uphold the sacred texts and fight anything that is not in the scriptures, confirm orthodoxy and destroy anything that is considered deviations (heterodoxy) and heresy (heresyi). As soon as a person enters into a circle of radical movements there is no longer a path to return (point of return) from continuing to live in jihad, or martyrdom. This kind of belief is very easy to find in the symbols used by bearers of radical movements. The sacred term of the Creed is often written together with the image of the sword that sustains it. Such symbolism contains the message that the witness (shahada) is war (jihad).

The realistic nature is a special feature that marks religion. Therefore, religion provides a powerful motivation to place its truth above all else, even above one's own life. Throughout the history of mankind, countless numbers of martyrs have proven the power of motivation. Religious motivation can make people desperate to endure the most cruel suffering, until death as a last consequence. In fact, the truth of religion is believed and cannot be proven. The believers also have no evidence that is still hidden for others. The reality of religion is based on mere faith, not on the visible. However, religious people are often more convinced about the truth of their religion than about many things that can be witnessed with their own eyes.

Epistemologically, we can see the root of violence in two ways, namely; which originates from within human beings themselves, as well as those from outside the human self, as a stimulus (stimulus) to the birth of acts of violence. An explanation of the epistemology of violence, including violence in the name of religion, also presupposes two sources, namely sources from within (internal) and external sources (external). Here we are dealing with what philosophy calls the epistemological roots of violence, namely violence from rooted from the inside (human self) which is instinctive and from the outside which is stimulus (stimulus).

For the epistemological roots of violence that are internal (in human and instinctive), we refer to the view of Konrad Lorenz who brilliantly explains that our tendency to nuclear war and other atrocities is not caused by biological factors beyond control. We like the social, political and economic conditions that we create, but are driven by human instincts as sources of energy that always flow and must always be channeled. So, it all happens is not always the result of reaction to external stimuli. Lorenz argues that the special energy for the instinctive action of humans accumulates continuously (continuously) in the nerve centers that are related to patterns of action by humans, including acts of violence The sacred texts are a set of teaching systems that overcome the social history of human life. Because of its character over time and space the religious text is fixed, both from the word and the content of its meaning. Therefore, the reality and development of human life must be completely subject to the text.

As a consequence of this kind of reasoning, radical groups view life as a lifelong jihad to uphold the sacred texts and fight anything that is not in the scriptures, confirm orthodoxy and destroy anything that is considered deviations (heterodoxy) and heresy (heresyi). As soon as a person enters into a circle of radical movements there is no longer a path to return (point of retrurn) from continuing to live in jihad, or martyrdom. This kind of belief is very easy 
to find in the symbols used by bearers of radical movements. The sacred term of the Creed is often written together with the image of the sword that sustains it. Such symbolism contains the message that the witness (shahada) is war (jihad).

The realistic nature is a special feature that marks religion. Therefore, religion provides a powerful motivation to place its truth above all else, even above one's own life. Throughout the history of mankind, countless numbers of martyrs have proven the power of motivation. Religious motivation can make people desperate to endure the most cruel suffering, until death as a last consequence. In fact, the truth of religion is believed and cannot be proven. The believers also have no evidence that is still hidden for others. The reality of religion is based on mere faith, not on the visible. However, religious people are often more convinced about the truth of their religion than about many things that can be witnessed with their own eyes.

Epistemologically, we can see the root of violence in two ways, namely; which originates from within human beings themselves, as well as those from outside the human self, as a stimulus (stimulus) to the birth of acts of violence. An explanation of the epistemology of violence, including violence in the name of religion, also presupposes two sources, namely sources from within (internal) and external sources (external). Here we are dealing with what philosophy calls the epistemological roots of violence, namely violence from rooted from the inside (human self) which is instinctive and from the outside which is stimulus (stimulus).

For the epistemological roots of violence that are internal (in human and instinctive), we refer to the view of Konrad Lorenz who brilliantly explains that our tendency to nuclear war and other atrocities is not caused by biological factors beyond control. We like the social, political and economic conditions that we create, but are driven by human instincts as sources of energy that always flow and must always be channeled. So, it all happens is not always the result of reaction to external stimuli. Lorenz argues that the special energy for the instinctive action of humans accumulates continuously (continuously) in the nerve centers that are related to patterns of action by humans, including acts of violence.[6]

Violent action is an explosion that occurs, when in the nerve had been collected enough energy even without the stimulation from the outside. Thus, according to Lorenz, acts of aggression and human violence are basically not reactions to stimuli from outside, but internal (internal) stimuli that are installed and seek outlet and will be expressed even with very little external stimuli, not even. The instinctive model of human aggression and violence, like Freud's libido model, is called a hydraulic model which is analogous to the pressure generated by water or steam in a closed tube. Lorenz's assumption is broader has also become the basis for the strong understanding of realism in human relations between nations.

Meanwhile, for the external epistemological root of violence, originating from outside the human self, as stimulus (stimulus) acts of violence, we can see in the view of a group of philosophers who are diametrically opposed to
Lorenz's opinion about instinctive roots of violence. They claim that violence is a manifestation of the stimulus (stimulus) obtained by humans from outside themselves. In general, this view is shared by environmentalists. Human actions exclusively (including violence) are created by environmental factors, namely by social, political, economic, cultural and so on, so not by "innate" instinctive factors. This is true, especially when it is associated with a violent phenomenon that is one of the impediments to human progress. This view, in its radical form, was put forward by enlightenment philosophers. Humans, according to Enlightenment philosophers, are born "good" and reasoning. Meanwhile, what makes them evil is the existence of institutions, structures and realities outside of human beings that exhibit bad examples.[7]

\section{CONCLUSION}

Based on a series of explanations above, on the integration of theological violence, the politics of human identity, and the epistemology of violence concerning internal-external roots, the philosophical solutions gained for the problem of theological violence are:

First, it can begin by asking: in what psychological conditions do religious actors resort to theological violence? This answer is necessary because as an explanation of instinctive violence that comes from within man, that internal root can also be a source of violence. They commit acts of violence such as assault, murder, suicide bombings and so on in the name of religion is when they experience severe mental depression. They are desperate in the face of the future (their version, according to which they aspire) that have been clogged due to the social, political, economic and other factors of society that are not very happy for them. [7]

Secondly, the answer that must also be sought is the question of things beyond human instincts that can provide stimulus (stimulation) to humans to carry out theological violence. Theological violence occurs when extremist leaders of a particular religion, (in their reaction to what they see as injustice in a structural environment of a society), have succeeded in using religious (or ethnicreligious) arguments to order others (their people) committing acts of violence. So the first stimulus comes from the factor of the religious leader who in the hierarchical context of the religious community is very controlling the community.

The second stimulus can come when theological violence is the result, excessive response and reaction to the emergence of injustice in the domestic (local) social, economic and political environment, even though it has nothing to do with religion. As long as injustice in these areas cannot be eliminated, theological acts of violence will be possible.

The third stimulus, states that theological violence arises from the imbalance and injustice of global (international) politics. This can be attributed to the theological acts of violence perpetrated by the hegemony and domination and repression of certain groups or countries uncontrollably. This hegemony, domination and repression then gave birth to injustice and poverty and gave rise to an 
epistemology of deep hatred among religious people. Injustice, poverty and hatred are then linked to interreligious conflict, especially if groups that hegemony, dominate and repress come from different religions. Or, even if it turns out to be from the same religion, it can be linked to intra-religious conflict.

From both of these, searching for answers to questions about philosophical solutions to theological violence will lead us, firstly to the study of the instinctive source of conflict, which is the implementation of the psychological state of man. This internal human expression should be carefully reviewed, viewed case by case, and in a broad context. This is necessary, because the psychological (psychological) conditions of humans are different and always changing. The introduction of the psychological character and the context of human differences and psychological changes that lead to violence will help us to find a solution to the practice of resolving theological violence, especially the source of the instinctive human psychological reason.

Furthermore, the philosophical solutions of theological violence, especially those involving stimuli from outside of the human self, are useful in the context of creating a strategy to challenge and overcome all forms of injustice, poverty, ignorance and so forth, in a structural environment of a society, both in a local, domestic context (national) and global (international).

In this case, the country and its bureaucratic instruments, and international political organizations, are obliged to create a balance of life among their citizens and minimize the potential for injustice, alleviate poverty and ignorance, and solve other societal problems. With the intervention of the state and international political organization, solving the problem of theological violence is expected to touch the roots of the problem. This simulative effort must also be accompanied by the willingness of religious circles to invite religious people to non-violence militancy such as Gandhi (Hindu), Martin Luther King (Protestant), Dalai Lama (Buddha), GusDur (Islam) and so on. The interference of the clergy will make efforts to solve the problem of theological violence reaching the public of the religious community widely. For intellectuals are expected to contribute, especially on the search for alternative solutions to the problems of human life on the basis of their respective knowledge. Their intervention is necessary in order to solve the problem of theological violence to be comprehensive, to reach all areas of life.

\section{ACKNOWLEDGEMENT}

This research was supported by Faculty of Social Sciences and Law, Universitas Negeri Surabaya. Thanks to the Universitas Negeri Surabaya, especially to Dean of the Faculty of Social Sciences and Law. Thank you also to colleagues Lecturer at the Faculty of Social Sciences and Law, Universitas Negeri Surabaya

\section{REFERENCES}

[1] M. R. Dayan and D. P. Selvaratnam, "Anti-Criminalization System for Perpetrators of Criminal Acts of Terrorism AntiCriminalization System for Perpetrators of Criminal Acts of Terrorism," no. October, 2014.

[2] Djelantik Sukarwasini, Terrorism; Psycho-Political Review, Media Role, Poverty and National Security. Jakarta: Yayasan Pustaka Obor, 2010

[3] R. Matić, A. Dremel, and M. Šakić, "Terrorism : Social Causes and Perspectives," J. Crim. Justice Secur., vol. 1, no. 1, pp. 4661, 2017.

[4] C. Kimball, When Religion Becomes Disaster. Bandung: Mizan Pustaka Religion., 2003.

[5] T. Sandler, "New frontiers of terrorism research: An introduction," J. Peace Res., vol. 48, no. 3, pp. 279-286, 2011.

[6] K. Lorenz, On Agression. New York: Harcourt Brace Jovanovich, 1966.

[7] See Abdul Muis Naharong, "Sacred Hardness and Terror," $J$. Paramadina Univ., 2005. 